\title{
Exogenous Application of Ascorbic Acid Enhances the Antimicrobial and Antioxidant Potential of Ocimum sanctum L. Grown under Salt Stress
}

\author{
Neelma Munir, ${ }^{1}$ Sheza A. Khilji, ${ }^{2}$ Maryam Shabir, ${ }^{1}$ and Zahoor A. Sajid $\mathbb{D}^{3}$ \\ ${ }^{1}$ Department of Biotechnology, Lahore College for Women University, Lahore, Pakistan \\ ${ }^{2}$ Department of Botany, Division of Science and Technology, University of Education, Lahore, Pakistan \\ ${ }^{3}$ Institute of Botany, University of the Punjab, Lahore, Pakistan \\ Correspondence should be addressed to Zahoor A. Sajid; zahoor.botany@pu.edu.pk
}

Received 30 April 2021; Revised 6 June 2021; Accepted 21 August 2021; Published 2 September 2021

Academic Editor: Shakeel Ahmed

Copyright $\odot 2021$ Neelma Munir et al. This is an open access article distributed under the Creative Commons Attribution License, which permits unrestricted use, distribution, and reproduction in any medium, provided the original work is properly cited.

Ocimum sanctum L. (Tulsi) is the most important medicinal plant that has antimicrobial, antioxidants, and anticarcinogenic effects on human health. Plants, when under stress, gather several antioxidants and osmoprotectants. The present work focuses on the abiotic stress response of Tulsi and its mitigation by the application of ascorbic acid. In addition to this, an enhancement of antioxidant and antimicrobial activity was also analyzed using ascorbic acid. During the present work, when plants were grown under $\mathrm{NaCl}$ stress and ascorbic acid (AA) was provided with foliar applications, it ascertained encouraging effects on growth; likewise, its effect remains stable under salinity stress. The enzymatic antioxidants activity showed a significant change in response to AA alone or in combination. The highest catalase activity was recorded in plants subjected to $0.5 \mathrm{mM}$ AA in combination with $100 \mathrm{mM} \mathrm{NaCl}$ ( 0.65 units/mL of enzyme). Likewise, a similar trend was recorded for the superoxide dismutase activity of Tulsi plants. The highest activity of SOD was recorded in plants subjected to $0.5 \mathrm{mM} \mathrm{AA}$ in combination with $100 \mathrm{mM} \mathrm{NaCl}(66.1$ units/mg of protein). Flavonoid content showed its highest amount $(27.41 \mathrm{mg} / \mathrm{g})$ when plants were treated with $0.5 \mathrm{mM}$ $\mathrm{AA}+100 \mathrm{mM} \mathrm{NaCl}$ while the highest phenolic content $(1.88 \mathrm{mg} / \mathrm{g})$ was analyzed in salt treated plants sprayed with $0.5 \mathrm{mM}$ AA. In the case of antimicrobial activity, $0.5 \mathrm{mM}$ AA treated plants gave the highest value for the Staphylococcus aureus as $2.15 \mathrm{~cm}$ and in Clostridium species was $2.1 \mathrm{~cm}$ in the plants treated with $1 \mathrm{mM}$ AA alone. Hence, the findings of the present study may lead to the conclusion that AA has a significant role in defense mechanisms of plants in response to salt stress. Further, it enhances the antimicrobial and antioxidant potential of Tulsi plants grown under salt stress.

\section{Introduction}

In the last few years, pharmacological industries became active in producing new antibiotics as microorganisms are becoming more and more resistant to the older drugs [1]. Folk medicines that include natural and herbal products have been utilized for centuries throughout the world. Along with a low adverse reaction rate, their cost is highly reduced [2]. Different parts of the plants are used for the extraction of different compounds that are efficient in curing cough, fever, bronchitis, cold, diarrhea, cholera, and dysentery, etc. [3]. Around the globe, one of the greatest economic value sources is a medicinal plant. Pakistan is one of the countries that are blessed with rich sources of botanical wealth [4]. Ocimum sanctum is one of the most important plants of genus Ocimum and is commonly known as "Tulsi" in Pakistan [5]. Generally, it possesses antifertility, anticancer compounds, antidiabetic, antifungal/antimicrobial, cardioprotective related compounds, analgesic, antispasmodic, and adaptogenic actions [6]. Eugenol (1-hydroxy-2methoxy-4-allylbenzene), the active constituents present in $O$. sanctum $\mathrm{L}$. have been found to be largely responsible for the therapeutic potentials [7]. The growth and productivity of medicinal plants are majorly hindered by abiotic and biotic stresses. Their medicinal properties are also severely affected by these environmental stresses. Whenever the 
stress conditions prevail, several imbalances occur in the plant physiology that consequently may influence therapeutic traits as well as the growth of these medicinal plants [8]. Salt stress is specifically considered as one of the important abiotic factors that limit the production of crops due to different types of stresses like osmotic disturbance, ionic imbalance, oxidative stress, and hormonal irregularities [9]. Vitamin C, also known as "ascorbic acid" (AA), is one of the most important and most abundant growth promoters presents in plants [10].

A small amount of AA produced endogenously is involved in the promotion of the development and growth of plant cells. This AA is involved in the phytohormonal mediated signaling pathways and is bound towards a various number of environmental stress conditions along with development and growth [10]. Ascorbic acid applied as foliar application helped in the protection against toxic derivatives of oxygen that has an adverse effect on many enzyme activities [11]. According to the biochemical studies, under the salinity stress condition, plants usually accumulate metabolites that are known as compatible solutes. These compatible solutes do not hinder the biochemical process occurring in the cell [9]. During sodium chloride stress, AA displayed an efficient effect by the accumulation of different soluble proteins and antioxidant enzymes. Stress-induced proteins and enzymes are generally produced under stress conditions that play a vital role in tolerating stress conditions [10]. It is well reported in literature that antioxidants contribute to preventing several diseases like cancer, heart, hepatitis, etc., since these antioxidants are scavengers of reactive oxygen species in the body [12]. Several genes are responsible for controlling abiotic stress tolerance [13]. Salt stress has been reported to reduce germination percentage, seedling vigor, and biochemical parameters like carbohydrate, protein, catalase, total phenols, and proline of Ocimum tenuiflorum [14]. Keeping in view the importance of ascorbic acid and the significance of Tulsi plants, the present study was conducted to investigate the changes in phytochemical constituents of the Tulsi plants in response to $\mathrm{NaCl}$ and AA alone or in combination. Additionally, an enhancement in antimicrobial and antioxidant activities by exogenous application of ascorbic acid was also investigated.

\section{Materials and Methods}

2.1. Cultivation of Ocimum sanctum L. Seeds of Tulsi plants were obtained from the Botanical Garden University of the Punjab Lahore (Pakistan). Tulsi seedlings were grown in earthen pots $(6 \times 9 \mathrm{~cm})$ having field soil mixture with Bhal and Manure in the ratio of $1: 1: 1$. Plants were grown in a glasshouse at $26 \pm 2^{\circ} \mathrm{C}$ temperature and $70 \%$ relative humidity under natural sunlight conditions.

\subsection{Application of Ascorbic Acid and $\mathrm{NaCl}$ Treatments.} The experiment was laid out in a completely randomized design with three blocks. Each block consisted of five replicates for each concentration. All pots in experiments were given simple water for 30 days. $\mathrm{NaCl}(0$ and $100 \mathrm{mM}$; Merk,
USA) was treated through roots drenching for each concentration. Then plants were provided with different concentrations of AA (0.1, 0.5 and $1.0 \mathrm{mM}$; Sigma Aldrich; MW 176.5) through a foliar spray. Tween-20 (polyoxyethylene sorbitan monolaurate; Sigma Aldrich) was added as a surfactant for penetration of AA into leaf tissues. Eight Treatments of both AA and salt were given simultaneously after 7 days for 60 days. The treatments were as follows:

(1) Control (Simple water with foliar spray of distilled water). (2) Plants treated with $100 \mathrm{mM} \mathrm{NaCl}+$ foliar application of distilled water. (3) Plants treated with $0 \mathrm{mM}$ $\mathrm{NaCl}+$ foliar application of $0.1 \mathrm{mM} \mathrm{AA}$. (4) Plants treated with $0 \mathrm{mM} \mathrm{NaCl}+$ foliar application of $0.5 \mathrm{mM}$ AA. (5) Plants treated with $0 \mathrm{mM} \mathrm{NaCl}+$ foliar application of $1.0 \mathrm{mM}$ AA. (6) Plants treated with $100 \mathrm{mM} \mathrm{NaCl}+$ foliar application of $0.1 \mathrm{mM}$ AA. (7) Plants treated with $100 \mathrm{mM}$ $\mathrm{NaCl}+$ foliar application of $0.5 \mathrm{mM}$ AA. (8) Plants treated with $100 \mathrm{mM} \mathrm{NaCl}+$ foliar application of $1.0 \mathrm{mM}$ AA.

\subsection{Collection of Plant Material and Estimation of Enzymatic} Antioxidant Activity. The healthy and fresh leaves were separated, and inflated polythene bags were used for the packaging of plant materials. The plants were rinsed under running water and were dried by the Whatman filter paper no. 1. Fresh leaves of about $0.5 \mathrm{~g}$ were measured and crushed with mortar and pestle to form a paste. About $1 \mathrm{~mL}$ of PBS (Phosphate Buffer Saline) having a pH of 7.2 was added to the paste along with $0.05 \mathrm{~g}$ of PVP (Sigma Aldrich). Slurry so obtained was centrifuged at $4^{\circ} \mathrm{C}$ for 10 minutes at $14,000 \mathrm{rpm}$ (wise spin CF-10, Germany). Supernatant was carefully collected for the estimation of antioxidant enzymes.

The method of Beers and Sizer [15] was used to estimate the catalase activity (E.C 1.11.1.6). Blank was prepared by adding $3 \mathrm{~mL}$ of $50 \mathrm{mM}$ phosphate buffer. The test sample was prepared by adding $2.9 \mathrm{~mL}$ of $0.036 \% \mathrm{H}_{2} \mathrm{O}_{2}$ solution prepared in phosphate buffer and $0.1 \mathrm{~mL}$ of plant extract. In this method, hydrogen peroxide disappeared was confirmed by taking absorbance at $240 \mathrm{~nm}$. This procedure took place at optimum $\left(37 \pm 2^{\circ} \mathrm{C}\right)$ conditions.

Superoxide dismutase (SOD; E.C 1.15.1.1) assay was performed with little modification in the method proposed by Sevilla et al. [16]. The reaction mixture was prepared by $1 \mathrm{~mL} \mathrm{NaCN}$ (Sigma Aldrich), $10 \mathrm{~mL}$ methionine, $10 \mathrm{~mL}$ EDTA, $1 \mathrm{~mL} \mathrm{NBT}$, and $1 \mathrm{~mL}$ of Riboflavin. The final volume was made up to $100 \mathrm{~mL}$ with buffer solution. Blank consists of $2 \mathrm{~mL}$ reaction mixture. The test was prepared by adding $5 \mu \mathrm{L}$ of extract along with the reaction mixture. The absorbance of both samples was measured at $560 \mathrm{~nm}$ by using a spectrophotometer (UV-9000S).

The Guaiacol- $\mathrm{H}_{2} \mathrm{O}_{2}$ method was employed, followed by Luck [17], to determine the peroxidase (E.C. 1.11.1.7) activity. Two test tubes $(15 \times 150 \mathrm{~mm})$, one having the reaction mixture consisted of $0.1 \mathrm{M}$ phosphate buffer $(\mathrm{pH} 7.2 ; 3.0 \mathrm{~mL}$; Sigma Aldrich), $20 \mathrm{mM}$ guaiacol (2-methoxyphenol) 0.05, and $0.1 \mathrm{~mL}$ crude enzyme extract. While in control, crude enzyme extract was replaced by $0.1 \mathrm{~mL}$ distilled water. Both test tubes were placed at $25 \pm 2^{\circ} \mathrm{C}$ and then added to $0.03 \mathrm{~mL}$ of $12.3 \mathrm{mM} \mathrm{H}_{2} \mathrm{O}_{2}$ solution. Enzyme activity was determined 
by the time required to increase the absorbance (UV-9000S) by a value of 0.1 (e.g., $0.4-0.5$ ) at $240 \mathrm{~nm}$ and expressed as $\mathrm{U} / \mathrm{mL}$ of the enzyme.

\subsection{Quantitative Analysis of Nonenzymatic Antioxidants.} The freshly obtained plant leaves were air-dried in the shade for 3-4 days at room temperature. The fully dried leaves were then ground in fine powder or dust by using mortar and pestle. Methanol $(100 \mathrm{~mL})$ and $20 \mathrm{~g}$ of air-dried powder were poured in a conical flask and kept on a rotary shaker for 24 hours (ShakerA by lab watch enterprises) at $150 \mathrm{rpm}$. Supernatant was collected, solvent vaporized to make one-fourth out of original volume by evaporating in a water bath (Daeyang ETS, Korea) and stored in sealed bottles at $4^{\circ} \mathrm{C}$ [18]. The total flavonoids content of the Tulsi plants was measured by means of a colorimetric method [19]. The extract $(250 \mu \mathrm{L})$ of Tulsi samples was mixed with $75 \mu \mathrm{L}$ of $5 \% \mathrm{NaNO}_{2}$ solution and $1.25 \mathrm{~mL}$ of deionized water. Afterward, $150 \mu \mathrm{L}$ of $10 \% \mathrm{AlCl}_{3}$ solution was added to this sample. The reaction was started by the addition of $0.5 \mathrm{ml}$ of $1 \mathrm{M} \mathrm{NaOH}$, making up volume up to $2.5 \mathrm{~mL}$ by adding deionized water. Absorbance was taken at $510 \mathrm{~nm}$ with the help of a spectrophotometer (UV-9000S).

The total phenolic components were examined with an improved method with slight modifications in the FolinCiocalteu reagent method [20]. Samples were prepared by adding $0.25 \mathrm{~mL}$ Folin-Ciocalteu (Merk) reagent, $0.25 \mathrm{~mL}$ of the plant extract in dilute form, and then $3.5 \mathrm{~mL}$ of distilled water was added to make a volume of $4.6 \mathrm{~mL}$. After this, $1 \mathrm{~mL}$ of $20 \% \mathrm{Na}_{2} \mathrm{CO}_{3}$ solution was added, followed by vortex mixing, and then samples were incubated at room temperature for two hours. For the blank reading, $0.25 \mathrm{~mL}$ of $80 \%$ methanol was added instead of the extract on a spectrophotometer (UV-9000S) at $765 \mathrm{~nm}$.

\subsection{Determination of DPPH Radical Scavenging Activity.} The total antioxidant activity of Tulsi extract was measured by using DPPH 1, 1- diphenyl -2-picrylhyrdazyl method after Ghafoor et al. [21] with certain modifications. One $\mathrm{mL}$ of the Tulsi extract $(100 \mu \mathrm{L} / \mathrm{mL}$ methanol) was thoroughly mixed in $2 \mathrm{~mL}$ of the solution of DPPH (10 mg DPPH was dissolved in $1 \mathrm{~L}$ methanol) and kept in this sample at $250^{\circ} \mathrm{C}$ for 5 minutes. The absorbance was measured at $517 \mathrm{~nm}$.

2.6. Antimicrobial Activity. Pathogenic bacterial strains including Clostridium sp. and Staphylococcus aureus were used for the determination of antimicrobial activity. The strains were obtained from the laboratory of the Department of Biotechnology, Lahore College for Women University, Lahore, Pakistan. These strains were maintained in the nutrient agar slants and were stored at $4^{\circ} \mathrm{C}$. The medium used for suspension bacterial culture was the nutrient broth. Strains of Clostridium and Staphylococcus aureus were inoculated at $37 \pm 2^{\circ} \mathrm{C}$ for $16-18$ hours in test tubes.

2.7. Statistical Analysis. All these experiments were set up in triplicate, and the data thus obtained was statistically analyzed by applying statistical software SPSS version 22.0.0 following the Duncan Multiple Range Test in order to compare the means for the selected parameters.

\section{Results}

3.1. Catalase (CAT, EC 1.11.1.6) Activity. The present study indicates that plants grown in the presence of salt stress gave a significant increase in the activity of catalase from 0.29 to 0.43 units $/ \mathrm{mL}$ of enzyme in control and salt treated plants, respectively (Figure 1). At the same time, AA treated plants helped to alleviate the effect of salt stress and hence gave a much higher catalase activity value to cope with salt stress. The maximum catalase activity was recorded in the salt treated $(100 \mathrm{mM} \mathrm{NaCl})$ Ocimum plants when treated with $0.5 \mathrm{mM}$ AA ( 0.65 units $/ \mathrm{mL}$ of enzyme).

3.2. Superoxide dismutase (SOD, EC 1.15.1.1) Activity. The present study indicated that SOD activity generally had an increasing trend in response to salt treatment. The plants treated with salt stress gave an increase in value from 33.0 to 40.7 units/mL of the enzyme (Figure 2), whereas the plants treated with $0.1,0.5$ and $1 \mathrm{mM} \mathrm{AA}$ along with $100 \mathrm{mM} \mathrm{NaCl}$ showed a significant increase in the value of SOD from 50.2, 66.1 and 50.8 respectively, which indicated a positive effect in the inhibition of salt stress conditions.

3.3. Peroxidase (POD, EC 1.11.1.7) Activity. The present study indicated that when plants treated with salt stress gave an increase in peroxidase activity from 2.6 to $3.6 \mathrm{mg} / \mathrm{g}$ of tissue. POD activity generally had an increasing trend as a result of AA treatment given to the salt-stressed plants. The plants treated with $0.1,0.5$ and $1 \mathrm{mM}$ AA along with $100 \mathrm{mM}$ $\mathrm{NaCl}$ gave a significant increase in the value of peroxides activity as $4.7,5.8$, and 4.8 , respectively (Figure 3 ).

3.4. Flavonoid Contents. During the present work, plants treated with salt stress showed an increase in the value of flavonoid contents from 10.38 to $22.39 \mathrm{mg} / \mathrm{g}$, whereas the plants treated with $0.1,0.5$ and $1 \mathrm{mM}$ AA along with $100 \mathrm{mM} \mathrm{NaCl}$ gave a significant increase in the value of flavonoid as 26.41, 27.41 and 25.39 respectively, which indicated a positive effect in the inhibition of salt stress conditions (Figure 4).

3.5. Phenolic Contents. During the present work, it was found that the total phenolic contents were significantly increased after the application of AA, which helped to alleviate the harmful effects of salt stress conditions (Figure 5). The plants treated with $100 \mathrm{mM} \mathrm{NaCl}$ gave an increase in value from 0.89 to $1.50 \mathrm{mg} / \mathrm{g}$, whereas the plants treated with $0.1 \mathrm{mM}, 0.5 \mathrm{mM}$ and $1 \mathrm{mM}$ ascorbic acid along with $100 \mathrm{mM}$ $\mathrm{NaCl}$ gave a significant increase in the value of total phenolic content as 1.6, 1.88, and 1.53, respectively, which indicated a positive effect in the inhibition of salt stress conditions.

3.6. Antioxidant Activity. During the present study, a DPPH test was performed for the determination of the nonenzymatic antioxidant activity. The plants treated with $100 \mathrm{mM}$ 


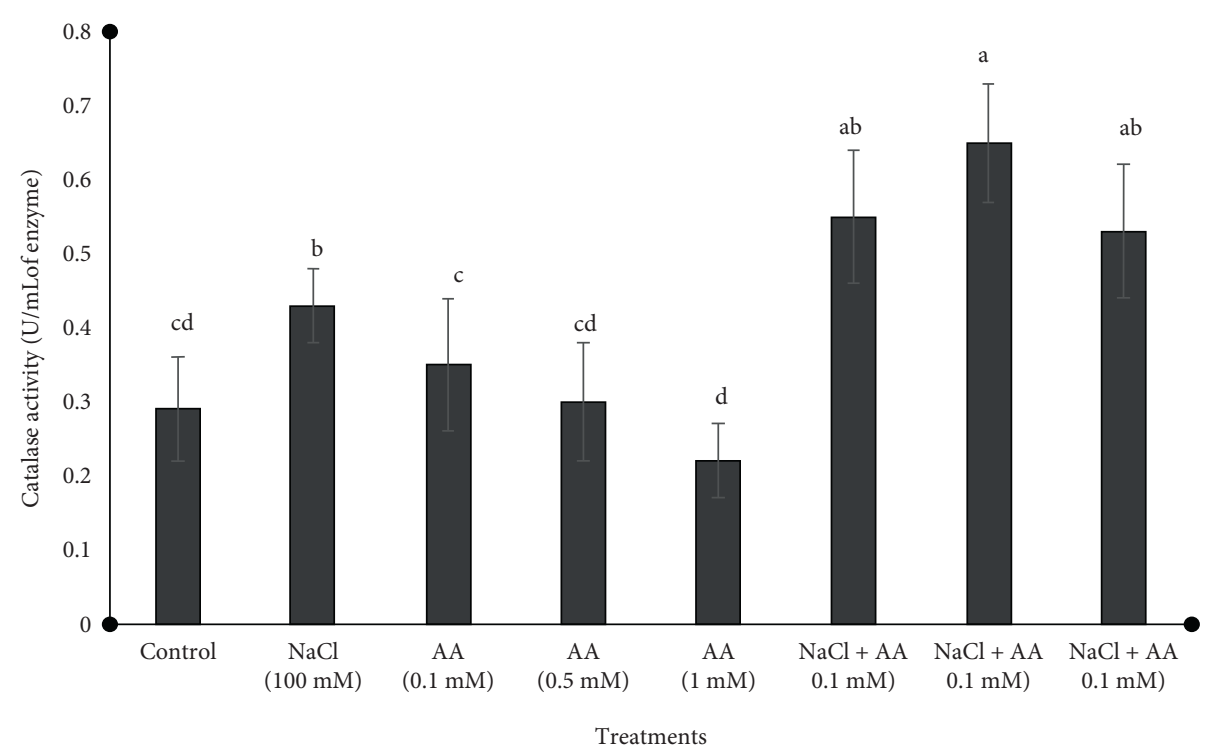

FIGURE 1: Effect of various ascorbic acid treatments on Tulsi plants subjected to salt stress on catalase activity.

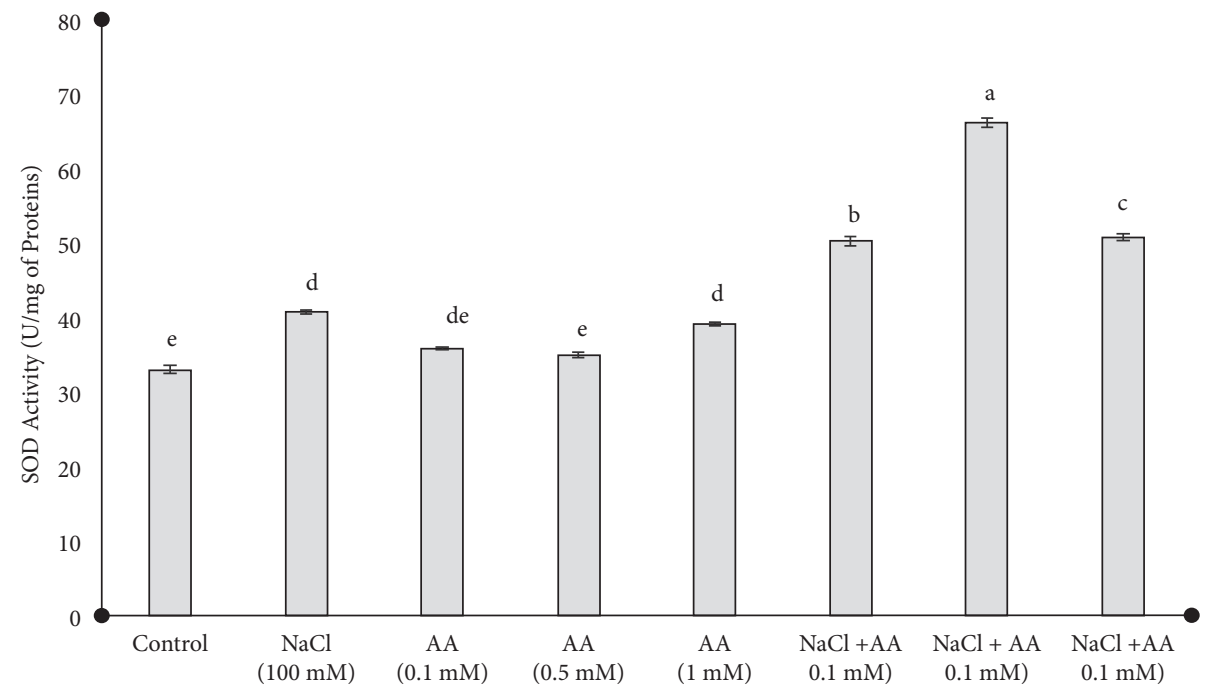

Treatments

Figure 2: Effect of various ascorbic acid treatments on Tulsi plants subjected to salt stress on superoxide dismutase activity.

$\mathrm{NaCl}$ gave an increase in value from $36.8 \%$ to $40.03 \%$ (Figure 6), whereas the plants treated with $0.1 \mathrm{mM}, 0.5 \mathrm{mM}$, and $1 \mathrm{mM}$ ascorbic acid along with $100 \mathrm{mM} \mathrm{NaCl}$ showed a significant increase in the value of antioxidant activity as $51.67,52.96$, and 50.63\%, respectively, which indicated a positive effect of treatment.

\subsection{Antimicrobial Activity of Extracts of Ocimum sanctum.} Ocimum sanctum is a medicinally important plant; hence, the antimicrobial effect has a great impact on its activity. It was used for the measurement of the effectiveness of treated plant extract against pathogenic bacteria. The plants treated with $100 \mathrm{mM} \mathrm{NaCl}$ gave an increase in the zone of inhibition from 1.9 to $2.1 \mathrm{~cm}$, whereas the plants treated with $0.1,0.5$, and $1 \mathrm{mM}$ AA along with $100 \mathrm{mM} \mathrm{NaCl}$ gave a significant increase in the zone of inhibition as $1.15,2.12$ and $1.6 \mathrm{~cm}$ as presented in Table 1 . This indicated a positive effect on antimicrobial activity. In the case of Clostridium species, antimicrobial activity was increased from $1.6 \mathrm{~cm}$ to $2.0 \mathrm{~cm}$ in the plants treated with $100 \mathrm{mM} \mathrm{NaCl}$, whereas the plants treated with $0.1,0.5$, and $1 \mathrm{mM}$ AA along with $100 \mathrm{mM} \mathrm{NaCl}$ gave a significant increase in antimicrobial activity as $1.9,1.25$, and $1.0 \mathrm{~cm}$, respectively.

\section{Discussion}

During the present work, an increase in catalase activity was observed in response to salinity. However, the negative results of salinity were reduced in response to ascorbic acid treatment. The activity of SOD was increased in response to AA application combined with the $\mathrm{NaCl}$ treatment indicating its possible role in salt tolerance mechanisms. These 


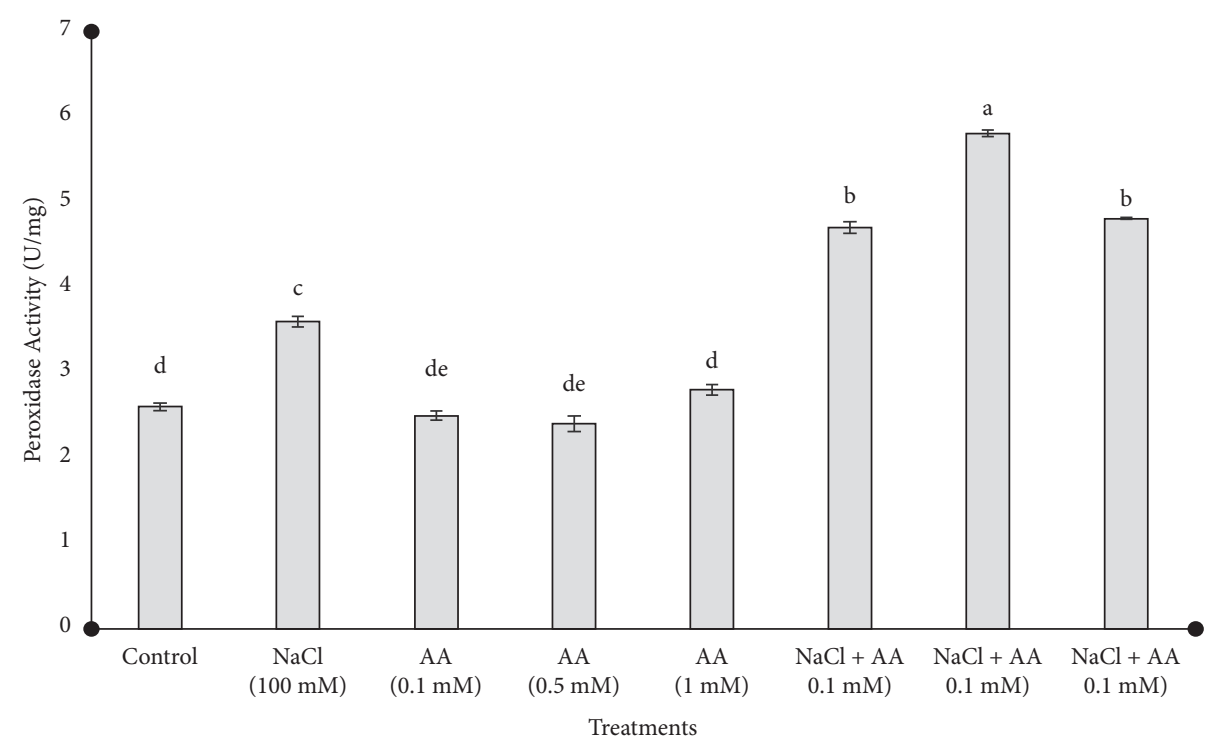

FIGURE 3: Effect of various ascorbic acid treatments on Tulsi plants subjected to salt stress on peroxidase activity.

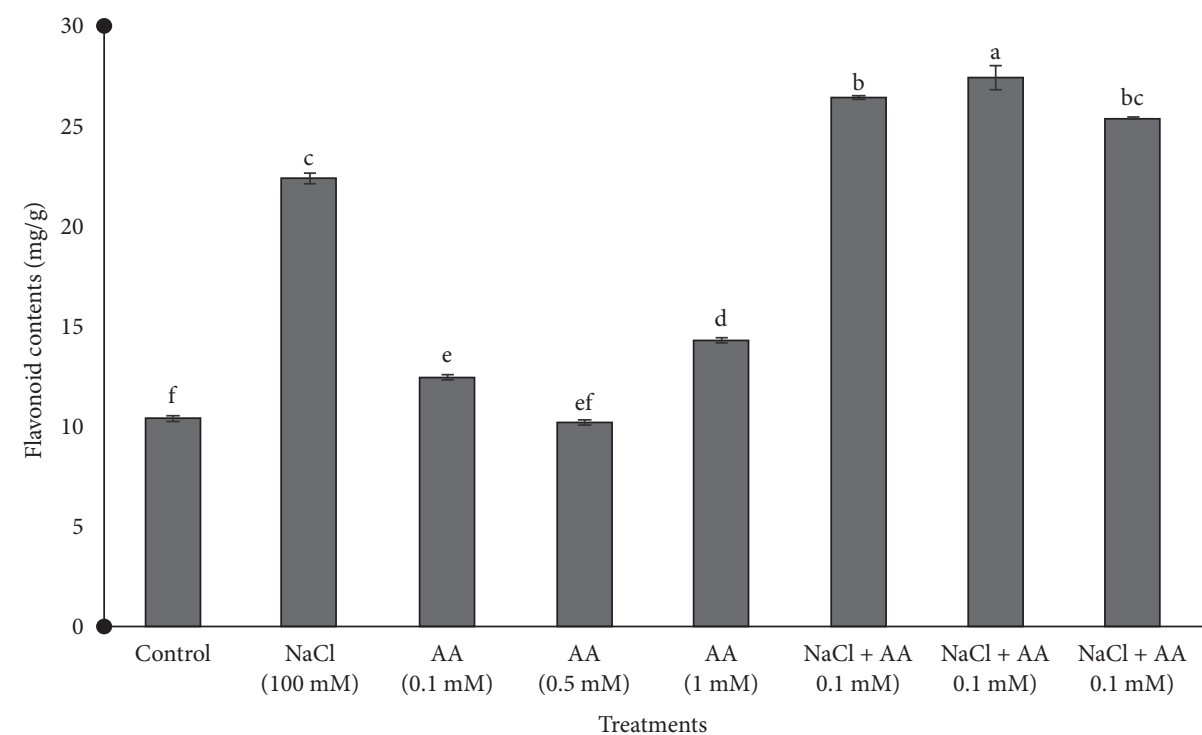

FIGURE 4: Effect of various ascorbic acid treatments on Tulsi plants subjected to salt stress on flavinoids contents.

findings are in accordance with findings of Nair et al. [22]; those observed positive effects of AA on O. sanctum for their antioxidant potential. Likewise, Gul et al. [23] also reported an increase in enzyme activity in response to salt stress when different concentrations of AA were applied, resulting in an increase in SOD activity in Cymposis tetragonoloba. In response to $\mathrm{NaCl}$ stress, an increase in catalase and SOD activities was linked to reducing the oxidative damage caused by reactive oxygen species (ROS) in potatoes and several other plants [24, 25].

An increase in peroxidase activity in response to different treatments of AA has indicated a positive effect in the inhibition of salt stress conditions during the present work. Peroxidase converts the $\mathrm{H}_{2} \mathrm{O}_{2}$ into water molecules. Likewise, Nair et al. [22] also reported an increase in peroxidase activity in response to AA. Flavonoids have radical scavenging activity; therefore, these are considered powerful antioxidants [26]. Phenols and flavonoids are important secondary metabolites present in medicinal plants. An increase in flavonoids during the present work is in line with the findings of Prasad et al. [27], who also reported an increase in flavonoid contents of five different medicinal plants in response to salt stress when different ascorbic acid levels were applied as a foliar spray. Similarly, Gaffar et al. [9] also reported an increase in phenolic, flavonoids, and tannins contents in response to foliar application of $\mathrm{AA}$ in common beans, growing under water stress conditions.

A positive effect of AA treatment in enhancing the antioxidant activity observed by DPPH assay indicated the role of $\mathrm{AA}$ in the inhibition of salt stress conditions. 


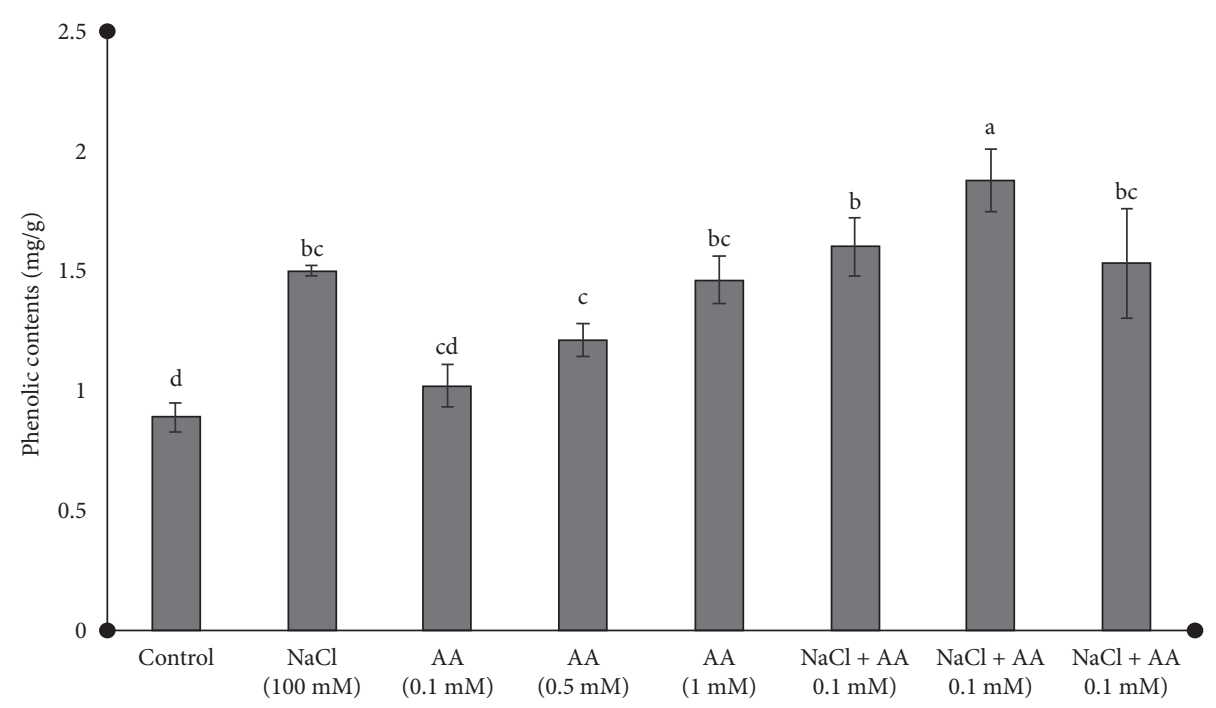

Treatments

FIgURE 5: Effect of various ascorbic acid treatments on Tulsi plants subjected to salt stress on phenolics contents.

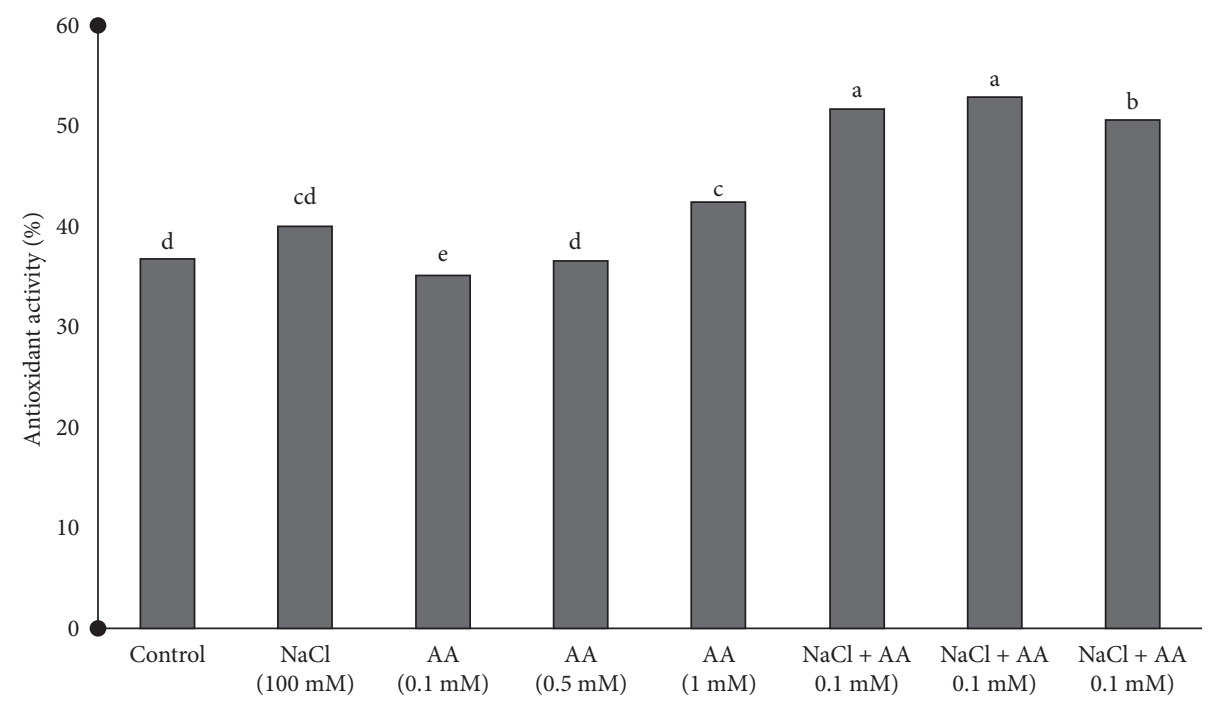

FIGURE 6: Effect of various ascorbic acid treatments on Tulsi plants subjected to salt stress on antioxidant activity.

TABLE 1: Effect of different treatments on the antimicrobial activity of leaf extracts of Ocimum sanctum against Staphylococcus aureus and Clostridium sp.

\begin{tabular}{lcc}
\hline & Staphylococcus aureus & Clostridium sp. \\
\hline Treatments & & Zone of inhibition (cm) \\
Control & $0.6 \pm 0.0^{\mathrm{e}}$ & $0.6 \pm 0.0^{\mathrm{f}}$ \\
Distilled water & $1.9 \pm 0.92^{\mathrm{b}}$ & $1.6 \pm 0.71^{\mathrm{c}}$ \\
$100 \mathrm{mM} \mathrm{NaCl}$ & $2.10 \pm 1.06^{\mathrm{a}}$ & $2.0 \pm 0.99^{\mathrm{ab}}$ \\
$0.1 \mathrm{mM} \mathrm{AA}$ & $1.85 \pm 0.88^{\mathrm{b}}$ & $1.37 \pm 0.55^{\mathrm{cd}}$ \\
$0.5 \mathrm{mM} \mathrm{AA}$ & $2.15 \pm 1.10^{\mathrm{a}}$ & $1.65 \pm 0.74^{\mathrm{c}}$ \\
$1.0 \mathrm{mM} \mathrm{AA}$ & $1.65 \pm 0.74^{\mathrm{c}}$ & $2.1 \pm 1.06^{\mathrm{a}}$ \\
$0.1 \mathrm{mM} \mathrm{AA}+100 \mathrm{mM} \mathrm{NaCl}$ & $1.15 \pm 0.39^{\mathrm{d}}$ & $1.9 \pm 0.92^{\mathrm{b}}$ \\
$0.5 \mathrm{mM} \mathrm{AA}+100 \mathrm{mM} \mathrm{NaCl}$ & $2.12 \pm 0.42^{\mathrm{a}}$ & $1.25 \pm 0.46^{\mathrm{d}}$ \\
$1.0 \mathrm{mM} \mathrm{AA}+100 \mathrm{mM} \mathrm{NaCl}$ & $1.6 \pm 0.71^{\mathrm{c}}$ & $1.0 \pm 0.28^{\mathrm{e}}$ \\
\hline
\end{tabular}

Means within a column followed by the same letter do not differ significantly $(P \leq 0.05)$ according to Duncan's multiple range test. Results are mean \pm S.E. 
Previously, an increase in antioxidant activity has been reported in three different medicinal plants when different growth regulators were applied as foliar applications [28]. Likewise, Choudhary et al. [29] also reported an increase in antimicrobial activity in response to salt stress when different growth regulators were applied as a foliar application to Ocimum sanctum. The phytochemical present in methanol extract was found to be more active against all of the bacterial species tested. Furthermore, extracts prepared from leaves are shown to have better efficacy and demonstrated that the secondary metabolites and antimicrobial agents are highly effective against several pathogenic bacteria.

\section{Conclusions}

Ocimum sanctum plants were tested for their response to salt stress alone and in combination with foliar application of AA during the present study. The Ocimum plants showed significant changes in flavonoids, phenolic, catalase, peroxidase, and SOD as these compounds are very significant for plant defense mechanisms, so this increase is of great significance to see the possible role of AA application in the amelioration of salinity tolerance. The concentration of the antioxidants and antimicrobial activity differ among various treatments given to $O$. sanctum plants. Differently treated plants of $O$. sanctum exhibited both enzymatic and nonenzymatic antioxidant defense systems to cope with the ROS under the salt stress condition. Ascorbic acid treatments resulted in greater activities of antioxidant enzymes (catalase, SOD, and peroxidase). Further, an increase in antimicrobial activity was also observed by the exogenous application of ascorbic acid. The obtained results provided some clues as to which of these responses may be affected by the foliar application of AA that helps in the defense mechanism of plants against salt stress. Hence, the results of the present study may be helpful in the mitigation of the negative effects of salt stress on Ocimum sanctum plants. These results also confirmed the potential use of exogenous application of ascorbic acid to enhance the antimicrobial and antioxidant activities of Tulsi plant grown under stress conditions; however, this study necessitates further work to test the effectiveness of ascorbic acid on other plants.

Means followed by the same letter do not differ significantly $(P \leq 0.05)$ according to Duncan's multiple range test in all figures.

\section{Data Availability}

The data used to support the findings of this study are included within the article.

\section{Conflicts of Interest}

The authors declare that there are no conflicts of interest regarding the publication of this paper.

\section{References}

[1] G. F. Nascimento Gislene, J. Locatell, C. Freitas Paulo, and L. Silva Giuliana, "Antibacterial activity of plant extract and phytochemical on antibiotic resistant bacteria," Brazilian Journal of Microbiology, vol. 31, pp. 247-256, 2000.

[2] M. G. Nair, G. R. Safir, and J. O. Siqueira, "Isolation and identification of vesicular-arbuscular mycorrhiza-stimulatory compounds from clover (Trifolium repens) roots," Applied and Environmental Microbiology, vol. 57, no. 2, pp. 434-439, 1991.

[3] B. Joshi, S. Lekhak, and A. Sharma, "Antibacterial property of different medicinal plants: Ocimum sanctum, Cinnamomum zeylanicum, Xanthoxylum armatum and Origanum majorana," Kathmandu University Journal of Science, Engineering and Technology, vol. 5, no. 1, pp. 143-150, 2009.

[4] J. B. Calixto, "Efficacy, safety, quality control, marketing and regulatory guidelines for herbal medicines (Phytotherapeutic agents)," Brazilian Journal of Medical and Biological Research, vol. 33, no. 2, pp. 179-189, 2000.

[5] G. R. Ghosh, "Tulasi (NO labiatae, genus-Ocimum)," New Approaches to Medicine and Health (NAMAH), vol. 3, pp. 23-29, 1995.

[6] E. M. Williamson, Major Herbs of Ayurveda, Churchill Livingstone, London, UK, 1st edition, 2002.

[7] A. Kicel, A. Kurowska, and D. Kalemba, "Composition of the essential oil of Ocimum sanctum L. grown in Poland during vegetation," Journal of Essential Oil Research, vol. 17, no. 2, pp. 217-219, 2005.

[8] S. M. Shahzad, M. S. Arif, M. Ashraf et al., "Alleviation of abiotic stress in medicinal plants by PGPR," Soil Biology, vol. 42, pp. 135-166, 2015.

[9] A. A. Gaafar, S. I. Ali, M. A. El-Shawadfy et al., "Ascorbic acid induces the increase of secondary metabolites, antioxidant activity, growth, and productivity of the common bean under water stress conditions," Plants, vol. 9, p. 627, 2020.

[10] T. A. Khan, M. Mazid, and F. Mohammad, "Ascorbic acid: an enigmatic molecule to developmental and environmental stress in plant," International Journal of Applied Biology Pharmaceutic, vol. 2, no. 3, pp. 468-483, 2011.

[11] F. Moradi and A. M. Ismail, "Responses of photosynthesis, chlorophyll fluorescence and ROS-scavenging systems to salt stress during seedling and reproductive stages in rice," Annals of Botany, vol. 99, no. 6, pp. 1161-1173, 2007.

[12] M. Kumar, M. Chandel, S. Kumar, and S. Kaur, "Studies on the antioxidant/genoprotective activity of extracts of Koelreuteria paniculata Laxm," American Journal of Biomedical Science, vol. 1, pp. 177-189, 2012.

[13] S. Rastogi, S. Shah, R. Kumar et al., "Ocimum metabolomics in response to abiotic stresses: cold, flood, drought and salinity," PLoS One, vol. 14, no. 2, Article ID e0210903, 2019.

[14] A. Gupta, V. Singh, P. Prasad et al., "Influence of potassium and sodium chloride on germination behaviour, biochemical changes, and enzyme activity in two varieties of Ocimum tenuiflorum L," Journal of Essential Oil Bearing Plants, vol. 24, no. 1, pp. 110-119, 2021.

[15] R. F. Beers and I. W. Sizer, "A spectrophotometric method for measuring the breakdown of hydrogen peroxide by catalase," Journal of Biological Chemistry, vol. 195, no. 1, pp. 133-140, 1952.

[16] F. Sevilla, L. A. Del Río, and E. Hellín, "Superoxide dismutases from a citrus plant: presence of two iron-containing isoenzymes in leaves of lemon trees (Citrus limonum L.)," Journal of Plant Physiology, vol. 116, no. 5, pp. 381-387, 1984.

[17] H. Luck, Methods in Enzymatic Analysis, Bergmeyer Academic, New York, NY, USA, 2nd edition, 1974.

[18] A. R. Singh, V. K. Bajaj, P. S. Sekhawat, and K. Singh, "Phytochemical estimation and antimicrobial activity of 
aqueous and methanolic extract of Ocimum sanctum L." Journal of Natural Product and Plant Resources, vol. 3, no. 1, pp. 51-58, 2013.

[19] C. C. Chang, M. H. Yang, H. M. Wen, and J. C. Chern, "Estimation of total flavonoid content in propolis by two complementary colorimetric methods," Journal of Food and Drug Analysis, vol. 10, no. 3, pp. 178-182, 2002.

[20] K. Ghafoor, F. Y. Al-Juhaimi, and Y. H. Choi, "Supercritical fluid extraction of phenolic compounds and antioxidants from grape (Vitis labrusca B.) seeds," Plant Foods for Human Nutrition, vol. 67, no. 4, pp. 407-414, 2012.

[21] K. Ghafoor, J. Park, and Y.-H. Choi, "Optimization of supercritical fluid extraction of bioactive compounds from grape (Vitis labrusca B.) peel by using response surface methodology," Innovative Food Science \& Emerging Technologies, vol. 11, no. 3, pp. 485-490, 2010.

[22] V. D. Nair, C. A. Jaleel, R. Gopi, M. Gomathinayagam, and R. Panneerselvam, "Antioxidant potential of Ocimum sanctum under growth regulator treatments," European Asia Journal of Bioscience, vol. 3, pp. 1-9, 2009.

[23] H. Gul, R. Ahmad, and M. Hamayun, "Impact of exogenously applied ascorbic acid on growth, some biochemical constituents and ionic composition of guar (Cymopsis tetragonoloba) subjected to salinity stress," Pakhtunkhwa Journal of Life Science, vol. 3, pp. 22-40, 2015.

[24] Z. A. Sajid and F. Aftab, "Amelioration of salinity stress tolerance in Solanum tuberosum L. by exogenous application of ascorbic acid," In Vitro Cellular \& Developmental BiologyPlant, vol. 45, no. 5, pp. 540-549, 2009.

[25] N. A. Akram, F. Shafiq, and M. Ashraf, "Ascorbic acid-a potential oxidant scavenger and its role in plant development and abiotic stress tolerance," Frontiers of Plant Science, vol. 8 , Article ID 613, 2017.

[26] M. A. Anagnostopoulou, P. Kefalas, V. P. Papageorgiou, A. N. Assimopoulou, and D. Boskou, "Radical scavenging activity of various extracts and fractions of sweet orange peel (Citrus sinensis)," Food Chemistry, vol. 94, no. 1, pp. 19-25, 2006.

[27] M. P. Prasad, K. Jayalakshmi, and G. G. Rindhe, "Antibacterial activity of Ocimum species and their phytochemical and antioxidant potential," International Journal of Microbiology Research, vol. 4, no. 8, pp. 302-307, 2012.

[28] S. B. Bole, R. Manju, M. Nagaraj et al., "Comparative study of antibacterial and antioxidant activity of plant extract-amla [Phyllanthus emblica L.] tulsi [Ocimum tenuiflorum L.] neem [Azadirachta indica A. Juss]," Pharmacophore, vol. 1, pp. 178-183, 2010.

[29] S. Choudhary, A. Zehra, M. Mukarram et al., "An insight into the role of plant growth regulators in stimulating abiotic stress tolerance in some medicinally important plants," in Plant Growth Regulators, T. Aftab and K. R. Hakeem, Eds., Springer, Cham, Switzerland, pp. 75-100, 2021. 